Historic, archived document

Do not assume content reflects current scientific knowledge, policies, or practices. 

Forest Service

\section{Composition of Root Pressure Exudate from Conifers}

4) Pacific Northwest

Forest and Range Experiment Station

\section{D.O. Ketchie and W. Lopushinsky}

Research Note

PNW-395

October 1981
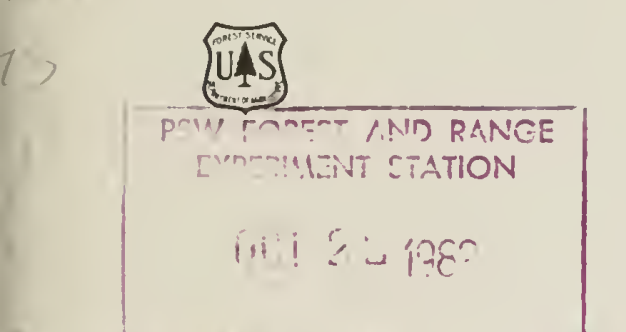

Abstract

Rbrt pressure exudates collected from detopped seedlings of Douglas-fir, grand fir, noble fir, Pacific silver fir, ponderosa pine, lodgepole pine, and Engelmann spruce were analyzed for sugars, amino acids, organic acids, nitrogen, potassium, calcium and magnesium. Sugar concentrations ranged from 0.10 percent to 5 percent, and included glucose, sucrose, fructose, and two unknowns, possibly rhamnose, and ribose. Amino acid concentrations ranged from 0.02 to 0.10 percent, and organic acids from 0.01 to 0.06 percent. Aspartic acid, glutamic acid and glutamine were the main amino acids in the exudates of all species with lesser amounts of glycine, serine, asparagine, arginine, leucine, and alanine. Nitrogen concentrations ranged from 0.005 to 0.012 percent, potassium from 0.006 to 0.018 percent, and calcium from 0.001 to 0.005 percent. Magnesium concentration was 0.001 percent in all species. The $\mathrm{pH}$ of the exudates ranged from 5.3 to 5.7. Except for the relatively high concentrations of sugar in the exudates from grand fir and noble fir, there were no species-related differences in amounts of the various constituents.

Keywords: Exudation, root exudates.

\section{Introduction}

Root pressure exudate from herbaceous and woody plants generally contains sugars, inorganic ions, organic acids, various nitrogen compounds such as peptides and amino acids, and growth regulators such as cytokinins and gibberellins. The occurrence of nitrogenous compounds in the xylem sap of hardwoods has been described by Bollard (1958). Less data are available for conifers, although Barnes (1963a) identified the organic nitrogen compounds in the extracted xylem sap of seven eastern and southeastern species of pines and showed that glutamine was the major amino acid present. Carter and Larsen (1965) reported similar results for loblolly pine (Pinus taeda L.). Little data are available on the composition of xylem sap of conifers native to the western United States, and we know of no studies which describe the composition of sap collected as root pressure exudate from western conifers.

In this paper we report the presence and concentration of sugars, free amino acids and inorganic ions in root pressure exudate collected from detopped, potted seedlings of Douglas-fir (Pseudotsuga menziesii (Mirb.) Franco), grand fir (Abies grandis (Dougl. ex D. Don) Lindl.), noble fir (Abies procera Rehd.), Pacific silver fir (Abies amabilis (Dougl. ex Forbes), lodgepole pine (Pinus contorta Dougl. ex Loud.), ponderosa pine (Pinus 
ponderosa Dougl. ex Laws.), and Engelmann spruce (Picea engelmannii Parry ex Engelm.).

\section{Methods}

Two-year-old bare-root seedlings were obtained from the Coeur d'Alene Forest Nursery in Idaho in March 1977, potted in 15.2-cm plastic pots in a peat moss-sand-perlite mixture, and kept in a greenhouse during the summer. During the following winter the seedlings were kept outdoors, mulched in beds of sawdust. In early March 1978, the seedlings were transferred to a cold room at $1-2^{\circ} \mathrm{C}$. A plastic bag was placed over the top of each seedling and sealed around the top to prevent seedling desiccation. Beginning in late May, 12-16 seedlings of each species were removed from the cold room one or two species at a time, detopped, and all tissues external to the xylem at the stump were removed.

Sap was collected in small glass reservoirs attached to the stumps. Exudates collected during the first 24-48 hours from 12-16 seedlings of a given species were combined to obtain a sufficient volume of sap for analysis. Exudates were kept frozen until needed for analysis. Because of bacterial contamination of exudates from the Douglas-fir seedlings, samples from this species were discarded. A separate group of seedlings was potted during the spring of 1979, grown and conditioned as described above, and exudate was collected during the first week of June 1980. Eight of the larger seedlings, which were in $19.0-\mathrm{cm}$ plastic pots, produced relatively large amounts of sap. Exudate samples from these seedlings were collected and analyzed separately to determine seedling-toseedling variation in type and concentration of constituents in the sap. Samples 1-4 and 5-8 were combined to obtain sufficient volume for analysis of $\mathrm{N}, \mathrm{K}, \mathrm{Ca}$, and $\mathrm{Mg}$. Exudate samples from eight other seedlings in 15.2-cm pots were combined to obtain a single composite sample. Details of the trend of exudation over time and water potentials of seedlings and exudates have been reported elsewhere (Lopushinksy 1980).

Immediately prior to analysis the samples were thawed. Three aliquots were taken from each sample-one for $\mathrm{pH}$, one for $\mathrm{N}$, and one for $\mathrm{K}, \mathrm{Ca}$ and $\mathrm{Mg}$ analyses. The remainder of each sample was then measured to determine volume, and the sample was filtered and 70-percent ethanol added to the filtrate. The solution was washed with chloroform and the chloroform phase was discarded. The ethanol solution was evaporated and the sample taken up in deionized water. Acids were isolated by passing the sample through Dowex $50^{1}(\mathrm{H})$ and Amberlite IR $45(\mathrm{OH})$ columns according to Williams and others (1950). The amino acids were removed from the Dowex column by washing with 10-percent ammonium hydroxide $\left(\mathrm{NH}_{4} \mathrm{OH}\right)$ and the $\mathrm{NH}_{4} \mathrm{OH}$ was then evaporated. Concentrations of total amino acids were determined with ninhydrin reagent as described by Lea and Rhodes (1954). A 1-ml aliquot from the amino acid sample was streaked on $5-$ by $5-\mathrm{cm}$ thin layer chromatography (TLC) plates and developed in an acetone-benzene-water mixture (70:23:6). After drying, the plates were sprayed with ninhydrin reagent and compared to plates streaked with standard amino acids for identification.

The organic acids were eluted from the Amberlite column with $1.0 \mathrm{~N}$ acetic acid and the acetic acid was then evaporated. Organic acid concentrations were determined by titrating with $0.02 \mathrm{~N} \mathrm{KOH}$ in methanol using phenol red as an indicator. Filtrates from the two columns were analyzed for sugars by the anthrone method described by Radin and others (1955). A 1-ml aliquot from the sugar sample was then streaked on 5 - by $20-\mathrm{cm}$ TLC plates, and the plates were developed in an ethylacetate-pyridine-water mixture $(80: 20: 10)$. After drying, the plates were sprayed with alpha napthol and sulfuric acid, and

\footnotetext{
${ }^{1}$ Mention of products or trade names does not imply endorsement by the U.S. Department of Agriculture.
} 
Results and Discussion

the sugars were identified by comparing the sample plates with plates that had been developed with standard sugars.

Nitrogen content was determined by the semimicro Kjeldahl method and $\mathrm{K}, \mathrm{Ca}$, and $\mathrm{Mg}$ concentrations were determined by atomic absorption spectrophotometry after dry ashing. The $\mathrm{pH}$ of the exudates was determined with a glass electrode. Amino acid, organic acid, and sugar concentrations were calculated as milligrams per milliliter of xylem sap, using alanine as the standard for amino acids, citric acid for organic acids, and glucose for sugars. Values were then converted to percents.

Sugars were the most abundant constituents in the exudates, followed by amino acids (table 1). Engelmann spruce was an exception with equal concentrations of sugar and amino acids. Grand fir exudate had the highest sugar content at 5 percent, followed by noble fir with 3.5 percent. The other species had less than 1 percent. Exudate from Engelmann spruce had the highest amino acid content at 0.10 percent. The other species contained $0.02-0.03$ percent.

Only a trace of organic acids, 0.01-0.02 percent, was found in the exudates from most species, except Engelmann spruce which contained 0.06 percent. Nitrogen content was 0.012 percent or less. Concentrations of nitrogen and amino acid did not appear to be correlated among the various species. For example, exudate from Douglas-fir contained the highest nitrogen concentration, yet had a relatively low concentration of amino acids. Values for $\mathrm{K}$ were about the same as for $\mathrm{N}$, except for exudate from Douglas-fir which had a relatively high $\mathrm{K}$ concentration. Calcium concentration was 0.005 percent or less for all species, and $\mathrm{Mg}$ concentration was only 0.001 percent. The $\mathrm{pH}$ ranged from 5.3 to 5.7 for the various species.

Table 1-Concentration of constituents in root pressure exudates of conifer seedlings

\begin{tabular}{|c|c|c|c|c|c|c|c|c|}
\hline Species & Sugars & $\begin{array}{l}\text { Amino } \\
\text { acids }\end{array}$ & $\begin{array}{l}\text { Organic } \\
\text { acids }\end{array}$ & $\mathrm{N}$ & k & $\mathrm{Ca}$ & $\mathrm{Mg}$ & $\mathrm{pH}$ \\
\hline & \multicolumn{8}{|c|}{--------- Percent --------} \\
\hline Engelmann spruce & 0.10 & 0.10 & 0.06 & 0.008 & 1 & 11 & 11 & 5.7 \\
\hline Grand fir & 5.00 & 0.03 & 0.01 & $1 /$ & $\underline{1}$ & 11 & 1 & 5.5 \\
\hline Noble fir & 3.50 & 0.02 & 0.01 & 0.005 & 0.008 & 0.005 & 0.001 & 5.5 \\
\hline Lodgepole pine & 0.38 & 0.02 & 0.01 & 0.010 & 0.006 & 0.002 & 0.001 & 5.3 \\
\hline Ponderosa pine & 0.80 & 0.03 & 0.02 & 0.007 & 0.008 & 0.001 & 0.001 & 5.3 \\
\hline Pacific silver fir & 0.24 & 0.02 & 0.01 & 0.008 & 0.006 & 0.004 & 0.001 & 5.5 \\
\hline Douglas-fir & 0.22 & 0.02 & 0.01 & 0.012 & 0.018 & 0.005 & 0.001 & 5.4 \\
\hline
\end{tabular}

Insufficient volume of solution to perform analyses. 
Sugar concentrations in exudates from the eight individual Douglas-fir seedlings ranged from 0.12 to 0.34 percent (table 2). Concentrations of amino acids ranged from 0.01 to 0.04 percent and organic acids from 0.01 to 0.03 percent. Only slight differences occurred in the case of $\mathrm{N}, \mathrm{K}$, and $\mathrm{Ca}$ where comparisons were based on two combined and one composite sample. Values for $\mathrm{Mg}$ were identical and $\mathrm{pH}$ did not vary among individual seedlings. Thus, except for the relatively high concentrations of sugar in the exudates from grand fir and noble fir, there do not appear to be any species-related differences in amounts of the various constituents.

Table 2-Concentration of constituents in root pressure exudates from individual Douglas-fir seedlings

\begin{tabular}{|c|c|c|c|c|c|c|c|c|}
\hline Seedling & Sugars & $\begin{array}{l}\text { Amino } \\
\text { acids }\end{array}$ & $\begin{array}{c}\text { Organic } \\
\text { acids }\end{array}$ & N & $K$ & $\mathrm{Ca}$ & $\mathrm{Mg}$ & $\mathrm{pH}$ \\
\hline Number: - & --- & -- & --- & - - Perc & cent - & --- & --- & -- \\
\hline 1 & 0.20 & 0.01 & 0.01 & & & & & 5.4 \\
\hline \multirow[t]{2}{*}{2} & 0.12 & 0.01 & 0.01 & & & & & 5.4 \\
\hline & & & & 0.011 & 0.016 & 0.007 & 0.001 & \\
\hline 3 & 0.23 & 0.01 & 0.02 & & & & & 5.4 \\
\hline 4 & 0.21 & 0.01 & 0.031 & & & & & 5.4 \\
\hline 5 & 0.13 & 0.02 & 0.01 & & & & & 5.4 \\
\hline \multirow[t]{2}{*}{6} & 0.25 & 0.03 & 0.01 & & & & & 5.4 \\
\hline & & & & 0.014 & 0.018 & 0.004 & 0.001 & \\
\hline 7 & 0.29 & 0.03 & 0.01 & & & & & 5.4 \\
\hline 8 & 0.34 & 0.04 & $0.01)$ & & & & & 5.4 \\
\hline S.E. ${ }^{1}$ & \pm 0.08 & \pm 0.01 & \pm 0.01 & \pm 0.001 & \pm 0.001 & \pm 0.001 & - & - \\
\hline Composite $^{2}$ & 20.18 & 0.02 & 0.01 & 0.011 & 0.019 & 0.005 & 0.001 & 5.4 \\
\hline
\end{tabular}

'S.E. = standard error.

${ }^{2}$ Combined sap samples from eight other seedlings.

TLC analysis for sugars indicated that exudates from all species tested contained glucose (table 3). Grand fir exudate contained five sugars: glucose, fructose, sucrose, and two unknowns which had the same rf values as rhamnose and ribose. The exudate from grand fir, lodgepole pine, ponderosa pine, and from one Douglas-fir seedling all contained an unknown, tentatively identified as rhamnose. Exudates from the two pines contained only two sugars, glucose and an unknown, possibly rhamnose. Except for the pines, there was no consistent pattern as to type of sugar present. Exudate samples from the eight individual Douglas-fir seedlings and the composite sample all contained glucose and an unknown, possibly ribose. Rhamnose was tentatively identified in only one sample. Each of the eight samples and also the composite sample contained all of the amino acids listed in table 3. 
Table 3-Sugars and amino acids in root pressure exudates of conifer seedlings

\begin{tabular}{lll}
\hline \multicolumn{1}{c}{ Species } & \multicolumn{1}{c}{ Sugars } & \multicolumn{1}{c}{ Amino acids } \\
\hline Engelmann spruce & \multicolumn{1}{c}{$\begin{array}{l}\text { Glucose, fructose, } \\
\text { sucrose, unknown 1, } \\
\text { unknown } 2^{3}\end{array}$} & $\begin{array}{l}\text { Aspartic acid, leucine, glutamine, } \\
\text { glutamic acid, glycine, serine. }\end{array}$ \\
Noble fir & Glucose, fructose \\
Lodgepole pine & Glucose, unknown $1^{2}$ \\
Ponderosa pine & Glucose, unknown $1^{2}$ & $\begin{array}{l}\text { Aspartic acid, asparagine, glutamine, } \\
\text { glutamic acid, glycine, serine, } \\
\text { arginine, leucine. }\end{array}$ \\
Pacific silver fir & Glucose & $\begin{array}{l}\text { Aspartic acid, glutamine, } \\
\text { glutamic acid, leucine. }\end{array}$ \\
Douglas-fir & $\begin{array}{l}\text { Glucose, unknown 1, } \\
\text { unknown } 2^{3}\end{array}$ & $\begin{array}{l}\text { Aspartic acid, arginine, asparagine, } \\
\text { alanine, leucine, glycine, serine, } \\
\text { glutamine, glutamic acid. }\end{array}$ \\
\hline
\end{tabular}

\footnotetext{
${ }^{1}$ Sugar concentration was too low for identification.

${ }^{2}$ Unknown 1 had the same if value on chromatograms as rhamnose.

${ }^{3}$ Unknown 2 had the same rf value on chromatograms as ribose.

${ }^{4}$ Unknown 1 was found in the exudate of only one of eight seedlings tested.
}

Aspartic acid, glutamic acid, and glutamine were the main amino acids in the exudates from all species. This finding is similar to the results reported by Barnes (1963a) and is to be expected since these compounds are the main amino acids involved in xylem transport of $\mathrm{N}$ and in the transamination process. Exudate from Douglas-fir also contained large amounts of leucine and alanine.

Nitrogen concentrations of the exudates ranged from 50 to $120 \mathrm{ppm}$ which is considerably higher than the 20 ppm reported by Barnes (1963b) for xylem sap of loblolly pine. Barnes' sap samples, however, were taken from branches of transpiring trees in which the sap probably was diluted by water moving in the transpiration stream.

There were no obvious relationships between the concentrations of exudate constituents and exudate volume, except possibly in the case of grand fir and noble fir. Both of these species contained much higher concentrations of sugars in their sap than the other species, and 30 hours after detopping had volumes of exudate 1.5-2.3 times the volumes measured for silver fir and the two pines (Lopushinsky 1980, fig. 1). 
Results in the present experiment may have been influenced by several factors. Bacterial contamination may have reduced sugar concentrations while sap was being collected, even before contamination was observed. Also, for all species tested except Douglas-fir, a single combined sample of sap was analyzed, and identification of sugars and amino acids was based on a single chromatographic determination. Consequently, the quantitative data for sugar and amino acid contents should be regarded more as estimates than precise values, and the identifications probably should be regarded as somewhat tentative. Nonetheless, as pointed out above', the amino acids identified as being predominant in the present experiment are the same as those reported for the xylem sap of other conifers.

The results of the present study suggest some interesting possibilities for further investigation. With large seedlings and precautions to prevent bacterial contamination, relatively large amounts of xylem sap could be collected from detopped conifer seedlings for considerable periods of time. This would facilitate studies of the active transport mechanism in conifer roots, and the effect of root environmental conditions or fertilizer nitrogen source on the chemical composition of xylem sap.

Metric Equivalents

\section{Literature Cited}

1 centimeter $(\mathrm{cm})=0.3937$ inch

1 milliliter $(\mathrm{ml})=0.001056$ quart (U.S. liquid)

1 milligram $(\mathrm{mg})=0.0003527$ ounce (avoirdupois)

Degree Celsius $\left({ }^{\circ} \mathrm{C}\right)=5 / 9\left({ }^{\circ} \mathrm{F}-32\right)$

Barnes, R. L. Organic nitrogen compounds in tree xylem sap. For. Sci. 9: 98-102; $1963 a$.

Barnes, R. L. Nitrogen transport in the xylem of trees. J. For. $61: 50-51 ; 1963 \mathrm{~b}$.

Bollard, E. G. Nitrogenous compounds in tree xylem sap. In: The physiology of forest trees. New York: New York Ronald Press Co.; 1958: 83-93.

Carter, M. C.; Larsen, H. S. Soil nutrients and loblolly pine xylem sap composition. For. Sci. 11:216-220; 1965.

Lea, C. H.; Rhodes, D. N. Phospholipids: 2. Estimation of amino nitrogen in intact phospholipids. Biochem. J.; 1954: 613-618.

Lopushinsky, W. Occurrence of root pressure exudation in Pacific Northwest conifer seedlings. For. Sci. 26: 275-279; 1980.

Radin, N. W.; Lavin, F. B.; Brown, J. A. Determination of cerebrosides. J. Biol. Chem. 217: 789-796; 1955.

Williams, K. T.; Bevenue, A.; Washauer, B. A study of the use of ion-exchange resins for the removal of non-sugar reducing substances in the analysis of fresh and dehydrated vegetables for reducing sugars. J. Assoc. Off. Agric. Chem. 33: 986; 1950. 

The Forest Service of the U.S. Department of Agriculture is dedicated to the principle of multiple use management of the Nation's forest resources for sustained yields of wood, water, forage, wildlife, and recreation. Through forestry research, cooperation with the States and private forest owners, and management of the National Forests and National Grasslands, it strives - as directed by Congress - to provide increasingly greater service to a growing Nation.

The U.S. Department of Agriculture is an Equal Opportunity Employer. Applicants for all Department programs will be given equal consideration without regard to age, race, color, sex, religion, or national origin.

Pacific Northwest Forest and Range

Experiment Station

809 NE Sixth Avenue

Portland, Oregon 97232 